\title{
IS ISLAM COMPATIBLE WITH DEMOCRACY? ISLAMIST MOVEMENT'S TRAJECTORY ON DEMOCRATIZATION IN INDONESIA
}

\author{
MUZAYYIN AHYAR ${ }^{1}$ \\ Institut Agama Islam Negeri Samarinda
}

\section{Abstract}

The democratization process in Indonesia is in line with the emergence several Islamic mass organizations which accept or rejected the concept of democracy. Since the pre-independence era, Indonesia has been facing some Islamist groups that opposed to state's ideology of democracy. This article presents the discussion among scholars about the compatibility between Islamic norms and democratic values, and in what position Indonesia is. The dealing question with the discussion is; does the proliferation of radical Islamist movement signify the incompatibility of Islam and democracy? By using sociological and historical approach, this paper analyzes in order to what extent the values of democracy and Islamism adapt in the frame of a democratic country. The analysis of this research results that the existing radical Islamist movement is not a failure of Indonesia's effort to harmonize Islam with democracy. Thus, neither the presence of pro-democracy Islamic mass organizations nor the radical Islamist movement cannot be used as the final argument to answer whether Islam compatible with democracy or not. The results of this study reveal that democratization in Indonesia has been accompanied by the proliferation of Islamist movements. The proliferation of Islamist movements nowadays precisely indicates that democracy in Indonesia has a special experience regarding new formula of peacefully religion-state relations.

Corresponding author; email: ${ }^{1}$ muz.ahyar@gmail.com

ISSN 0852-7172 (p) 2461-064X (e)

(C) 2017 Walisongo: Jurnal Penelitian Sosial Keagamaan

http://journal.walisongo.ac.id/index.php/walisongo 
Proses demokratisasi di Indonesia berjalan seiring lahirnya berbagai organisasi masyarakat Islam yang mendukung maupun menolak demokrasi. Sejak era pra-kemerdekaan hingga era reformasi, Indonesia terus dihadapkan dengan fenomena gerakan Isalmisme yang bersebrangan dengan ideologi Negara. Artikel ini menghadirkan diskusi yang selama ini masih banyak didiskusikan mengenai kesesuaian Islam dan demokrasi, dan di mana posisi Indonesia dalam hal kesesuaian dan ketidaksesuaian Islam dan demokrasi tersebut. Pertanyaan kunci dari artikel ini apakah proliferasi gerakan Islamis radikal menandakan ketidaksesuaian Islam dan demokrasi? Dengan menggunakan pendekatan sosiologi dan historis, artikel ini menganalisis sejauh mana nilai-nilai demokrasi dan Islamisme beradaptasi dalam bingkai Negara yang demokratis. Hasil analisis dari kajian ini menemukan bahwa eksistensi gerakan Islamis radikal bukan sebuah pertanda akan kegagalan usaha keras Indonesia dalam mengharmonisasikan Islam dan demokrasi. Sehingga, kehadiran ormas Islam, baik pendukung maupun penolak demokrasi, keduanya tidak dapat dijadikan jawaban final bahwa Islam sesuai atau tidak dengan demokrasi. Hasil dari kajian ini menekankan bahwa demokratisasi di Indonesia selalu diwarnai dengan proliferasi gerakan Islamis. Proliferasi gerakan Islamis akhir-akbir ini justru membuktikan bahwa demokrasi di Indonesia memiliki pengalaman khusus terkait formula hubungan agama-negara dalam masyarakat yang demokratis.

Keywords: Islamism; Indonesia's democracy; Islam and democracy; social movement.

\section{Introduction}

Imagine the following conditions: you live in a house with only one entrance and exit door. On the right side of the door, the warning written indicates that you are free to walk anywhere out of the house, as long as you should remember the way back to the house. On the other side, the warning written you should not leave this house for security reasons, because of many dangers are out there. Even if you insist on getting out of the house, 
you have to bring full security tools, which inhibit your moves. This condition is certainly confusing; getting freedom by considering individual's responsibility, or being imprisoned for security reasons.

The above illustration describes the Muslim society in Indonesia. Geographically, Indonesian Muslims live in a country that embraces a democratic system to appreciate freedom. Yet spiritually, they are bound to the normative teachings of Islam that impose and positions individual's freedom under the Islamic dogma. Those who believe this normative teaching of Islam, are willing to live in control and limitation for safety in the eschatological context. Freedom and imprisonment are the opposite words. In a political context, these two always appear in some post-world war countries, where some developed countries are trying to embed democracy into their hegemonic political system. The nationalism spirit which arises among post-war society is divided into two major parts; secular nationalism and religious nationalism. Mark Juergensmayer calls it as the new cold war; two nationalism established a concrete description of the supporters of freedom and imprisonment in one area (Juergensmeyer 1993).

Supports of the two mainstream Islamic organizations in Indonesia, Muhammadiyah and Nahdlathul Ulama (NU), against the democratic government, are often seemed as the evidence of the harmony between Islam and democracy. The democracy level in Indonesia shows a pretty good growth. Despite being fluctuating, the democracy index shows a satisfying trend. The growth of democracy in Indonesia is indicated by civil liberties, political rights, and the democratic institutions that are constantly moving upwards since 2009 to 2013, with a percentage up to 62.63-67.30 percent ("Indonesia's Democracy Index Report 2009-2013" 2014). Such growth is inseparable from the 
increasingly widespread globalization. Access to education is becoming more open, that seems to grow public awareness on the civil rights and freedom, and they are no longer willing to be controlled by authorities, either religious institutions or the Government. By 2015, some large and heterogeneous provinces in Indonesia, such as DKI Jakarta, Yogyakarta, and East Kalimantan were experiencing a rise in the index; these three provinces were decided as the most democratic provinces.

On the other hand, during the fluctuating growth of democracy index in Indonesia, this country experiences shocks from the violations in the name of religion that occurred in the last two decades. The proliferation of Islamic movements eventually damages the harmony between Islam and democracy demonstrated by the members of Muhammadiyah and NU as the two mainstream Islamic organizations in Indonesia. Islamic movements are deemed threatening and undermining the democracy of all aspects, particularly civil and political rights. Some cases like sacrilege, a desecration, and contempt of religion have proven that religious norms should direct the community freedom, including in internum areas.

The proliferation of Islamist groups in Indonesia leads to debates and become the topic of discussion among scholars in Indonesia. Some questions emerged regarding the debates on Islam and democracy; does the proliferation of radical Islamist movements signify the incompatibility of Islam and democracy? And to what extent the Islamist groups give the attention to the development of democracy in Indonesia?

By looking at the socio-political behavior of Indonesian Muslim community, this research does not seek to impose an Islamic discourse whether Islam is compatible or incompatible with democracy. I try to attempt to explore the social phenomena that occur related to debates among several intellectuals over 
the compatibility between Islam and democracy. The results of such exploration will become the subject of analysis to confirm that Islam provides interpretive norms which could be adjusted or disputed with any interest. Therefore, this article looks the famous Islamist group since the pre-independence day until the Reformation era in Indonesia. By utilizing the sociological and historical method, this article tries to analyzes this proliferation of Islamist groups in it relations to the discourse of compatibility of Islam and democracy. The analysis of proliferation of Islamist groups in the contemporary Indonesia will become the purpose that have to investigate in this article.

\section{Islam and Democracy in Discourse}

The year of 1924 was the end of the Islamic empire as a political system. The authority of the Turkey Ottoman with its major role in the expansion of the territories and the Islamization collapsed as the effect of the world war. The collapse of Turkey Ottoman dynasty signifies the initial contact of Islam and democracy.

Democracy is a political system that is now popularly embraced by many countries since the post-industrial revolution. The emergence of democracy in the global community indicates changes in the mindset of the community, which was previously imprisoned by the monarchy system of the government. The monarchy tended to be authoritarian, neglecting the human nature of being free; then, democracy was born to give hopes. People in the era of the monarchy were not treated fairly and their interests were not accommodated by the Kingdom. They were then attracted with the concept of democracy, which was perceived to offer more justice than monarchy. In the future, democracy would bring fresh air for the promises to liberate men that became the victims of injustice. 
Merphin Panjaitan revealed democracy means the rule of the people, who together govern themselves, appoint some of them to manage the countries and serve the society according to their will. For him, according to the purposes and the methods, democracy is a combination of the means and the goal. This is unlike the dictatorship that separates purposes and methods, as all things will be done to achieve goals (Panjaitan 2011).

In the context of Indonesia, many prominent figures of independence, such as Mohammad Hatta voiced the significance of democracy. Hatta wrote the importance of democracy for countries dreaming of the whole sovereignty, including Indonesia. The writings of Hatta were then collected and reprinted in 2014. According to him, democracy is a system of elections and government that is at its best when accompanied by a sense of responsibility. Hatta predicted that Indonesia's democracy will continue to grow and will never disappear; democracy could not be replaced with the monarchy although today, a crisis of democracy seems to occur.

Robert Dahl said that although democracy has variants-we could see democracy in the United States, France, the United Kingdom, Australia etc. are different-all forms of democracy exist for guaranteeing civil rights, justice, equality of political rights and freedom of the individuals. All of the things that democracy offers are almost realized (Robert A. Dahl and Shapiro 2015).

Born as a reaction towards the popular system of the ancient government (absolute monarchy), democracy is actually a way to insist freedom, justice, the sovereignty of the people, broad participation, as well as responsibility. All values contained in a democracy are having very little or no correlation of values on the authoritarian government. Ernest Gellner emphasized fairness and welfare in democratic nations. Gellner revealed a 
theory of congruency, that agricultural societies are congruent with patrimonial culture, as well as authoritarian government. As a consequence, such system gave birth to uprisings within the community due to economic, social and political disparities. Meanwhile, the industrial community is congruent with the nation-state, which is also congruent with a democratic government. The impact would be the creation of broad justice, participation and welfare. For him, democracy is a prerequisite for the creation of a good civil society.

In line with Ernest Gellner, Bernard Lewis, a renowned orientalist poured his ideas in a book entitled "What Went Wrong?" The core of this book is some of the questions surrounding Islam, degradation of Islamic civilization and state (since the establishment of Umayyah dynasty) and was often found as a chaotic state in socio-political affairs, especially after the collapse of Turkey Ottoman into several nation-states. The basic questions of Lewis were "What was wrong?" "Who did this to us (Muslim)".

This question gave birth to a conspiracy theory or blaming. Two great civilizations, namely Persia and Turkey were regarded as responsible for the decline of the Arab civilization on the Abasiyah dynasty. The Mongols as the executor of the collapse of the dynasty also played a role in the decline of Islamic civilization. Questions evolve, not only "Why was Islam destroyed?" but also "Who was to blame?", "What Is Islam?" It turns out that these questions are less relevant to the decline of Islam. Then, another question arose, "What Muslims did to Islam?"

Lewis explained some of the Muslim groups that caused retreat of Islam until the mid-20 $0^{\text {th }}$ century was the clergy or ' $u l a$ $m a$, who spread the doctrine of the past romanticism of glorious Islam, that for any problem, the solution was simply to Islam, and the reformist-fundamentalists who were old-minded 
and only concerned religious issues. Lewis arose another question "What are the mistakes we did?" and "How do we justify it?". Then, Lewis offered three keys for movement of Muslims; one of them is democracy. Democracy can mark as the key to the advancement of Muslims as long as Islam could release its doctrine that Islam is a way of life or al-Islam huwa al-hal or al-Isläm huwa al-dìn wa al-daulah. Some of the earlier doctrines made Lewis conclude that Islam is incompatible with democracy, whereas democracy and secularization are the only way to overcome adversity (Lewis 2002).

Two other keys that Lewis offered to rise from adversity are secularization and gender equality; the last mentioned is becoming a topic of discussions of a female Muslim intellectual from Morocco, Fatima Mernisi. She assumed that when Muslims in some Islamic countries are faced with democracy, there would be anthology of fear. The fears she perceived include fear of the West, human rights, gender equality, modernization, globalization, and others, that were brought together by the West through technology, such as telephones, televisions, and computers. However, the big question would be "If they accept technology, why do they avoid democracy?"

Samuel Huntington seemed to see Islam as the enemy for the West. He perceived that the most civilization against Western hegemony in the days to come is Islam. This is because Western concepts are not in accordance with Islamic teachings, which determine to have its own government system than to participate in the popular system (democracy). With some varying experiences, Huntington assumed that Islam is an anomaly for Western democracy (Huntington 2007).

In contrary to Huntington and Lewis who consider Islam as a religion that incompatible with democracy and the political conception of the West, Nazih Ayubi assumed that Islam 
could comply with democracy. He analyzed six Arab countries where many Islamic political movements are ongoing. He found that the conflicts happening is not merely a rejection of Muslims against the West that were built with sentiment, but rather a cultural and social responsibility to some existing gaps because of an immature democracy. One of his great ideas is: Muslims do not need to abandon the doctrine, just apply the democratic system in their own country! Practicing democracy doesn't mean leaving Islam. In fact, the political phenomena of Islam in the Arab world are a cultural and moral response to the crisis which hits and develops in Arab. Indeed, Islam only teaches common values, which are of great value to think and realize together, not only by seeing the past, as the context would be very different from today, as the impact of development in the modern world.

In discussing whether Islam is a religion of politics, it is worth considering the statement of Nazih Ayubi in his book "Political Islam: Religion and Politics in the Arab World". In accordance with the facts and arguments about the history of Islam, religion, and power system, Ayubi wrote: "I have repeatedly argued in this work that although Islam is a religion of collective morals, it is not particularly a political religion."

Abdullahi Ahmed an-Na'im agreed to such statement, that Islam does have compatibility with democracy. Nonetheless, he is more focused on the issues of positive law, justice, and human rights. He believed, Shariah as the law of the State should be deconstructed. Countries applying the principles of Shariah law should understand that these are not in accordance with universal laws that serve as an umbrella in reaching justice.

The world is now not just a monopoly of Muslims, so the verses of the law must be reinterpreted to conform with the principles of global justice. Civil rights and political rights of the community will be bound inside the Islamic states, and on the 
contrary, will be free in democratic secular states. (An-Na'im 2009)

The two latter Muslim intellectuals are those who attempted to reconcile the tension between "Islam" and "the West" which are fighting in terms of ideology. Efforts to reconcile between Islam and modernity (including the system of democracy and the secular state) are also done by some scholars, like Fathi Osman who concentrates on the relationship between religion and the application of human rights in Islam, John L Esposito, and James Piscatori. For them, Muslim need not lose their identity only because they adhere to the principles of democracy or human rights. Furthermore, Islam actually has a doctrine of syürā (mutual consultation), which close to the principles of democracy (Esposito and Piscatori 1991), and also huqūq Allāh huqūq an-nās which also mentions the concept of human rights (Osman 2001).

Religion is a broad thinking and opens to interpretation, as proven through the diversity and some variants. Therefore, religion often raises pros and cons, ambiguity and paradox even in one of the teachings. For example, syūrāa (mutual consultation) concept gives birth to various interpretation; some interpret this concept as similar to democracy, while others believe this is deliberation in Islamic version. On the other hand, many Muslim countries who adopt this concept, also run the authoritarian government system. The interpretation of syūra has confirmed that religious teachings can sometimes produce ambiguous and paradoxical things.

Because of the broad nature of the religion, the debates over the conformity of Islam to democracy would never end. The attacks from democracy advocates against Islam fundamentalist continue to widespread. Furthermore, the Muslim who reject democracy would not stop to voice disadvantages of the demo- 
cratic system. In fact, the attacks done by Islam fundamentalist are with arguments and logics using concepts of democracy.

There are five focuses of the arguments often used by Islam fundamentalists in resisting democracy. These efforts are what Masdar Hilmy calls as "fighting democracy from within". First, their argument is centered on the claim for truth. Democracy advocates often refer Islam fundamentalists as a radical group as they try to impose their will and claims over a single truth. However, the democracy advocates are often assessed to act the same, as they regard democracy as the absolute political system and reject the truth proposed by others, including Islamic groups.

The second argument is related to freedom of expression. Islamic groups have argued that the democracy supporters, especially those of the Western countries including the US and its allies, are inconsistent in implementing freedom of expression in public life. The Islamists stated the striking prohibition of religious symbols in France can also be considered an undemocratic act done by a country upholding democracy.

Third, the Islamic groups focus their arguments on the multiculturalism principles promoted by democracy. Western countries are considered forceful in embedding multiculturalism towards minorities. They argue in some democratic states, Muslim minority is urged to submit their credentials and forced to assimilate themselves to the majority, in this case, Christian identity. The rights of the majority are preserved, while the rights of the minority are crippled. Such discourse spreads in countries that adhere to the system of democracy.

Political elections also become the topic to debate between the Islamists and democracy supporters. In their view, the supporters of democracy have been using double standards in terms of advocacy and development of democracy in Muslim countries. The establishment of democracy has always been char- 
acterized by the institutionalization of political choice, that is a general election. The Islamists perceive Western countries as not serious in doing campaigns of national elections in Muslim countries. They are watchful of the victory that the Sharia-based party might gain in the election. They should set further standards or strategies; in other words, the result of the elections should benefit the West. If the result is considered detriment, the West will try to intervene in the political journey of the Muslim countries, as in Al-Jazeera and Egypt.

Fifth, the attention of the Islamists is centered to the consistency of democratic nations in the implementation of the secular principles, where the State could not intervene religion affairs, and vice versa. Religion will be the private affair, while the country is the public affair. The State should not interfere in the private areas. The Islamists argue that most countries embracing the democratic system are inconsistent in this regard. One example is, when a state governs how their people dress, while this is actually an expression of Islamic identity. A ban on Muslim women wearing hijab is one of the policies that violate the principle of secularism. There is also another example; in the United States, a public policy more often reflects Protestant Christian religious acts. Hence, Jeffrie Geovanie stated that the United States is not a secular country, but tends to be a Protestant country, especially when Republicans take control in the Congress (Geovanie 2013, 202).

Asep Bayat, a Muslim intellectual who examines Islam through a sociological approach, attempts to overcome the disputes between democracy and Islam. The question of whether Islam is in accordance with democracy, is irrelevant since it will give rise to the monolithic essence that narrows the corpus of Islam, that the true Islam is a democratic Islam (for those who believe that Islam is in accordance with democracy), while another 
Islamic model is perceived as wrong. On the other side, some organizations hold that the true Muslims must avoid democracy because it is not in accordance with Islamic values. Still according to Bayat, the more appropriate question is: Under what conditions democracy can be applied and how Muslims can be able to implement democracy? (Bayat 2007).

The long debates that have taken place could not be reconciled by Asep Bayat's thesis. In the course of the Islam world and democracy (especially in Indonesia), theoretical debates transform into debates in the praxis realm. The Islamists who are opposed to democracy are no longer debating the conformity of Islam to democracy. They even try to transform in various movements (through organizations or political parties), using the logic of democracy while persistently fighting for spreading the Islamic values.

Nevertheless, the discourses of Islamism and democracy led some scholars to argue many predictions. Sidney Jones argued that Indonesia will become terrorism field for the territorial independent struggling. According to Jones, the emerging of terrorist group in Indonesia's experiences signifies the important issues regarding national security. Indonesia will trap in the serious conflict after democratization in1998. The tragedies of social conflict in Ambon, Aceh, and Poso have demonstrated enough about the complexity of the emerging of terrorist groups.

This phenomenon also indicates the disillusionment with reform which properly brings the social-political realm of Indonesia better than before. In the first decade after reformasi, terrorism did not become the main issues of Indonesia political circumstance. For the political elite, there were far more important issues: rising corruption; stalled democratic reform; the impact of political Islam; the consequences of decentralization and maneuvering for the 2004 elections. The less awareness of ter- 
rorism issues, make some Islamist actors feel free to consolidate their identity of Islamism in the middle euphoria of democratization (Jones 2004).

\section{Democratization and Islamism in Indonesia: an Overview}

The democracy in Indonesia runs very dynamically on its' early age until for some parts, the journey process is ready to be measured to investigate the development. Data which were processed by Indonesia's Democracy Indicator (IDI) can be a standard for measuring democracy development in Indonesia. Indonesia's democracy indicator measures democracy based on three aspects: civil freedom aspect, political rights, and institutional democracy aspect.

Civil freedom aspect usually always related to self-expression freedom, movement freedom and freedom from arbitrary arrestment. This civil freedom aspect consists of four key variables which will be measured: freedom of being together and united, freedom of speech, freedom of belief and freedom from discrimination. Political rights aspect covers freedom to vote and to be voted, political participation of monitoring and choice taking. While democracy organization has five variables to be measured: free and legal election, Dewan Perwakilan Rakyat (DPR, People's Representative Assembly) role, political party role, and local government bureaucracy role and independence judicature.

From all indicators which were gotten on each variable, IDI found that the trend of Indonesia's democracy experiencing fluctuated number since 2009. On IDI 2012 achievement, civil freedom got the highest score and then followed by democracy institution which got an average score, and political rights aspect which got a low score. The index number of civil freedom was still higher than two other aspects (political rights and de- 
mocracy institution). But if it is compared to the previous year, the index of civil freedom experienced decreasing for about 2.85 points. The decreasing was believed as the effect of the existence of violation threatening or violation used by a society which obstructed the freedom of speech (score 43.94). It means that the freedom of speech faces a bigger challenge from society, not from government or country apparatus. On political rights aspect, mass rally with the violation (score 19.12) which happened in some provinces gave a contribution to the low index score of the aspect.

Generally, IDI scored that Indonesia's democracy was on moderate condition, in which the condition was secure enough for the third country which is in the process of building the democratic value. The latest measurement of IDI on 2013 showed that the percentage of Indonesia's democracy was on $63.72 \%$, the number was higher than the previous year, but lower than 2009 when Indonesia was on election nuance.

Some variables which were scored by IDI were very appropriate with the want of democracy repairmen which was formulated in an international conference by International Commission of Jurist. In the conference, the emphasized theme was about the dynamic aspect of law arrangement. A country with democracy government system must take a step based on the law which has been reached together. It is said that there are some basic requirements to conduct the democracy government based on rule of law which covers six things (Budiardjo 2003, 176):

1. Constitutional guarantee, which means that constitution, must also establish the procedural way to get the protection of the human rights.

2. Independent Justice institution

3. Free general election 
4. Freedom of speech

5. Freedom of being united/organization and opposition

6. Civic education

Robert Dahl gives critic to the current democracy development. According to Dahl, societies with some different ideologies have bigger willing to be lead with democracy system since there are three strong reasons. First, democracy promotes individual and collective freedom, in which cannot be promoted by the authoritative government. Second, democracy promotes human development by obeying individual choice, morality independence, and individual rights as long as the individual choice is responsible to the nation sustainability. Third, democracy can convince the society to protect their interest as a part of the nation like economic and political interest. The interest is protected by the promise of transparency and freedom which is brought by democracy continuously. However, when the promotions which are brought by democracy are facing obstacles; the political elite must prepare to get threatening from the sides which get disappointed by democracy promotion (Robert Alan Dahl 1989, 311).

Three aspects which become characteristics of democracy system country can be a boomerang for the democracy interest itself. It because the three aspects cannot be maintained yet well; so the maturity on the implementation of democracy system does not happen yet. The effect that emerges is those aspects can be a device for the democratic opposition to attack the country. If the effect is not realized, slow but sure, democracy is on the disorder threshold as the political phenomena in Uni-Emirates countries which try to adopt democracy system.

Thesis about democracy threatening is the apprehensive theme of Graham E. Fuller in a book entitled Democracy Trap. 
According to Fuller, democracy can be such a trap when the aspects which follow democracy (as freedom, guarantee of politic and civil right, and society participation) stimulate social-politic disorder, the effect of politic fight misunderstanding. Misunderstanding happened after the cold-war passed, which democracy made the world full of developmental promises. When the developmental promises could not be realized yet, all political groups competed in the middle of the transparency of democracy country will try to take the power away precisely to implement the authoritarian solution (Fuller 1992, 2-6).

Hundreds of millions of Indonesia society from various ranges of ethnics, culture, language, and religion make up the causa materialist of the Indonesian nation. The diversity in identity is freely expressed by the community but is subject to Bhine$k a$ Tunggal Ika (unity in diversity) slogan. The 40-year of the national movement, 22-year old order era, 31-year new order era, and 19-year reform era have made the country as a laboratory for the scholars in politics and democracy. Various models of democracy have been introduced by previous nation figures.

Moreover, several academics divide periods of democratization in Indonesia into several phases, such as the initial phase of the trial of democracy, guided democracy, and democracy of Pancasila, up to the actual process of democratization after the collapse of the new order regime (Ricklefs 2008). All of these models bring consequences for socio-political life in Indonesia, such as political turmoil, conflict of interests, conflict of the identity of rulers, and identity movements based on primordialism (Ricklefs 2008).

The traces of the democracy spirit can actually be traced back since the Netherlands colonialism in Indonesia. The social gap between the natives, Netherlands, China and Arabia at the end of the $19^{\text {th }}$ century sparked the voices of protests from 
indigenous communities. This social gap had an impact to the economic disparity between indigenous workers and Chinese workers. From the initial application of the Dutch ethical policy until 1925, Chinese workers and some who worked on the plantations and factories owned by Europe and China got average earnings of 370 Gulden per family or equivalent to $\$ 148$ per year. Meanwhile, the indigenous working as farmers and casual laborers earned 101-120 Guilders annually (Kahin 1952, 20).

These conditions made Samanhudi, who represented indigenous Islamic student-trader, to start a social movement. He was able to mobilize existing resources by using poverty of the indigenous with the spirit of Islamic struggle. In the early $20^{\text {th }}$ century, the Netherlands government began a new era of Dutch ethical policy in Indonesia. The support for applying such political system was led by Conrad Theodore Van Deventer who opened an opportunity for indigenous youth to actively join organizations and have formal education (Nasihin 2012, 27).

Referring to the political opportunity theory in social movements, the ethical policy was used by Samanhudi in mobilizing conflicts against the Netherlands Government policy by establishing an indigenous social organization concentrating in economics or trade, known as Sarekat Dagang Islam (SDI). This ethical policy raised a democratic awareness among society in the colonial era to become more politically independent.

Since its independence, Indonesia already implemented the democracy based on the consensus as mentioned in the Fourth Principle of Pancasila. The founding fathers have built awareness of democracy since the beginning through various agendas of the Investigating Committee for Preparatory Work for Indonesian Independence (BPUPKI) and Committee for Preparatory Work for Indonesian Independence Indonesia (PPKI). In the administration of Soekarno, the political turmoil following the 
Presidential Decree of 5 July 1959 urged Soekarno propose a model of democracy called the guided democracy. Simply, the democracy is a system in which the freedom of voice and politics should end up in the hands of Soekarno. President Soekarno was the one who made decisions related to various voices of freedom. Such kind of democracy was considered the embodiment of the character of Soekarno as a dictator (Ricklefs 2008).

However, it seemed that Soekarno did it all for maintaining the stability of Indonesia as the new nation, which was then split into three political identities: Nationalists, Islamists, and Communists. Since Indonesian independence, Islam has been in touch with the democracy in the country. Nahdlatul Ulama as a political party was close to Soekarno, however, the Majelis Syuro Muslimin Indonesia (Masyumi) as an Islamic party opposed the Soekarno's guided democracy. Thus, it was evident that differences of interpretation of the Muslim community took place in facing democracy.

Some organizations, including Masyumi, perceived guided democracy as another form of authoritarianism. The political system was considered using the mask of democracy, but with less democratic practices (Maarif 1996, 47) The removal of Masyumi from the coalition during the era inhibited their political movement. Also, few publishers and newspapers supporting Masyumi were banned. The culmination of the resistance of Muslim community against the guided democracy was seen when they firmly rejected the idea of nasakom (nationalism, religion, and communism). Nasakom illustrated that only three parties could participate actively in the national development and revolution, as those parties were close to Soekarno, namely the Indonesia National Party (PNI) representing Nationalism, NU for religion, and Indonesian Communist Party (PKI) for communism. 
This made Masyumi was kicked off from the political system in Indonesia. In the 1960s, Masyumi was officially closed, regulated under Presidential Decree No. 200 the year 1960. Other Islamic groups which rejected the concept of nationalism and democracy were DI/TII (Darul Islam/Tentara Islam Indonesia) led by Sekarmadji Maridjan Kartosoewirjo. Kartosuwirjo was a comrade-in-arms of Soekarno and a student from Hadji Oemar Said (HOS) Tjokroaminoto. After independence, Kartosoewirjo did a number of protests against government policies, as he believed Indonesia was still being enslaved by the Netherlands. He protested the policy, such as the state foundation, and the Renville agreement that were perceived to narrow the sovereignty of the Republic of Indonesia. After a long resistance since 1949, Kartosoewirjo was executed in 1962 with the indictment of treason, rebellion, and murder of the several leaders of the Republic of Indonesia (Al-Chaidar 1999).

The political wind changes from Soekarno era to the New Order era brought a new chapter in the nation's democratization. During Soeharto's administration, Pancasila was embraced and it was not just a motto voiced from one podium to others, but rather should be a guideline for citizens. Pancasila acted as the sole principles embedded into political and civic organizations, that began with issuing TAP MPR No. II/1978 concerning Socialization of Pancasila values. Soeharto's regime established the standard interpretation of Pancasila ideology called Pedoman Penghayatan dan Pengamalan Pancasila (P4, Guidelines for Instilling and Implementing Pancasila). In that era, democracy was to maintain nation's stability and social justice. In the field of economy, Soeharto was considered successful in bringing Indonesia from the economic slump to a country that was economically stable, despite the repressive political-economic policies (Schwarz 2008). 
In 1985, Soeharto promulgated that all mass organizations and political parties to accept Pancasila as the sole foundation (famous by penerapan asas tunggal). This application of sole foundation often gets resistance from Islamist movement, including Muhammadiyah as mainstream Islamic mass organizations in Indonesia. This sole foundation should make essential values of democracy are subject to the authoritarian regime of Soeharto.

Vehement opposition to the sole foundation also comes from various organizations that frontally against the new order government. Various radical movements are opposed to Pancasila as the sole foundation; one of the confrontational movements is the Darul Islam (DI) in Surakarta that leads by Abdullah Sungkar and Abu Bakar Ba'asyir. After getting out from DI, Sungkar and Ba'asyir formed Jama'ah Islamiyah (JI) in January 1993. The opposition of the sole foundation and new order regime intensified. Jama'ah Islamiyah condemns the new order regime as an enemy that must be fought because it's oppressive policy to the Islamist movement interest by formalizing Pancasila as the sole foundation and forbid Islam as the foundation of the organization.

Therefore, some Islamist cannot speak loudly to criticize the government. New order regime regarded as käfir mahāly (Muslim who adopted the political and governmental system without in the name of Islam and make an ideology other than Islamic law as the basis of the country). According to JI, käfir mahāly is more dangerous than käfir ajnabi (the person who obviously with disbelief to Islam, they occupy Muslim countries like Afghanistan and Palestine). The kāfir ajnabī so dangerously because of his hypocrite and exploitation of other Islamist movement for his profit (Solahudin 2011, 274). Finally, Sungkar must be earned as a political prisoner, while Ba'asyir emigrated to Malaysia to avoid the new order regime. 
The frequent political policy which is opposed by the Islamist movement community brought Soeharto tried to domesticate the Islamist movement to get closer to his political circles. In 1990 Soeharto sponsored the establishment of Ikatan Cendekiawan Muslim se-Indonesia (ICMI, Indonesian Association of Muslim Intellectuals). However, ICMI is widely opposed by the Muslim intellectuals such as Johan Efendi, Abdurrahman Wahid, and Deliar Noer. They considered ICMI as being exclusive, elitist, sectarian and consisting of bureaucrats and technocrats rather than intellectuals (Hilmy 2010, 77). 1991 was an important moment for political Islam in the new order era in Indonesia. In that year, Soeharto and his family went to Mecca to perform the haji pilgrimage. This moment is unusually hajj for Islamist movement people. This event has a great impact on the political Islam in Indonesia; who the famous authoritarian actor from "abangan" transformed to be an actor of "santri". This moment of hajj also affected the growth of Islamic symbols in public sphere. Mbak Tutut, Soeharto's eldest daughter, and a popular figure, began to demonstrate her piety publicly by wearing colorful, elegant headscarves. The Islamic greeting "assalamu'alaikum" in the opening passage of speech (especially for cabinet members) is becoming increasingly popular. In the context of mounting competition among elites, religion has become tremendously politicized and has served more as a tactical tool used by political contenders in their own interests (Hasan 2008).

After the collapse of new order regime from political power, Indonesia felt the new democracy experience. Some movements with affiliated identities to religion, ethnic group, political ideology, profession etc. has emerged in the public sphere. Religious identity is the most "popular product" for selling to the society. Since the reformasi era, various movements base on Islam 
has been quickly thriving as expression euphoria of wide spaces freedom. Various Islamic social movements have spread around big cities of Indonesia like Jakarta, Solo, and Yogyakarta. In the social movement theory, the emergence of Islamic movement is the consequence of democratization that give some promises more than poor and prosperity issues which popularly called by relative deprivation theory.

New social movements described by some Islamic Non-Governmental Organizations (NGOs) nowadays constitute another set of the widely used meso-level organization. Islamic movements not only promise the prosperity and provide social services, but they use social interactions with local communities to propagate and recruit followers as well. This condition makes the sound ideology of Islamism spread out louder after the reformasi.

Indonesia's case is not only the one experience in order to formulate the acculturation of Islam and democracy. The other experience can be seen in Iran revolution 1977-1979. Islamist movement in Iran did not arise when given an opening or political opportunity. Instead, the Islamists' aggressive mass rallying was directed at the part of the lid that had not been opened. Political opportunity argument fails to explain why Islamists decide to mobilize at a time (in the end of 1977) when Shah Pahlevi was reverting to a repressive stance. If Indonesia had suffered the economic crisis before the Reformation, then the economic explanation fails to analyze the emergence of the Islamist movement.

Observing Iran in early 1978, economic data would probably not have led us to predict that a revolution would soon occur (See Kurzman 2009). Kurzman's explanation on Iran revolution emphasizes that Islamist movement should not be preceded by democracy nature. Islamist movements do not emerge of democracy, but precisely causes of democracy. 


\section{Islamist Movement in Indonesia's Ongoing Democratization}

The Incessant agenda of Muslim intellectuals to promote the compatibility of Islam and democracy in Indonesia also accompanied by radical actions which injure the democratic values. For example in the cases of "deviant" sects in Indonesia; such as Shia, Ahmadia, Saksi Jehova etc. The guaranteed religious freedom by the constitution, in fact, should be limited by the sectarian argument of government regulations. The appraisals of good citizens have double standards; obeying the law, and holding the orthodox majority of religious interpretation. In the end, the followers of "deviant" sects in Indonesia trapped in a labyrinth of citizenship and orthodoxy of religious interpretation (Ahyar 2015b). Indeed, All these regulations are not in favor yet of freedom and human rights, the regulations were inherited from prior authoritarian Indonesian regime (the old order and new order). Hence, the government regulations regarding "deviant" sects are not currently able to protect their rights in the context of a democratic society (Alfitri 2008).

After the collapse of Soeharto's authoritarian regime, Islamist movement became a common phenomenon in Indonesia for enforcing their radical action; sweeping and bombing. From that day forward, Indonesia seems to pass through the tunnel of radicalism. Social science scholars, policymakers and the general public have paid attention phenomenon and tried to discuss to achieve a good solution for solving the problem which has threatened nation-state identity in Indonesia. Some scholars argued that Islamic radicalism is a consequence of social situation which in the unstable period of political transition to democratic era. Some of them also predicted in the ongoing democratic consolidation in Indonesia, radical Islamist movements will be defeated and dissappear slowly (Barton 2005) tracking down leading Jamaah Islamiyah (JI). 
Radical Islamist movements become internationally increase after the incident of Boeing commercial jet plane type, American Airlines Flight 77 crashed World Trade Center (WTC) and headquarter of Defense Department of United States (Pentagon) buildings on 11 September 2001. The United States proclaimed that it was a terror by Al-Qaeda; declaration was announced through international medias by slogan "war against terrorism". After that incident, reactions were done by some Islamist movements emerged in some countries. Around five years after the incident, the international world seemed surpass the terror excavation.

In Indonesia, the radical actions are often perpetrated by Front Pembela Islam (FPI, Islamic Defenders Front), Forum Umat Islam (FUI, The Islamist movement Forum) and several Islamist movements. Some terror series also happened as like Bali bomb, 12 October 2002, suicide bomb on JW Marriott Hotel on August 2003 and some other incidents with smaller scale in some regions such as Kuningan, Cirebon, Klaten, and Solo. In national scale, Solo became considerable cation radical Islamic movement. The radical actions and Islamism in Solo are not only known from the movements which are declared by Abu Bakar Ba'asyir as like Jamaah Islamiyah (JI, 1998), Majelis Mujahidin Indonesia (MMI, 1999), or Jamaah Anshorut Tauhid (JAT, 2008), but also emerged other local Islamist groups such as Hawariyyun, Islamist movement, Front Pemuda Islam Surakarta (FPIS), Laskar Jundullah, Laskar Umat Islam Surakarta (LUIS, Muslim Vigilante Groups of Surakarta).

It cannot be denied that civil freedom, political rights of each citizen, and independent democratic institutions are the special characters of a country which use democracy system. Those three aspects as like a river flow which must be passed by every citizen when living in a democracy flow. Some groups like Isla- 
mist movement try to fight against the democracy flow because of afraid and apprehensive about the future which was crashed by stones in the flow.

The efforts against the flow which were done continuously by Islamist movement was indeed an effort to actualize themselves and repositioning an identity which trapped as long the authoritative government and adversary toward terrorist stigma. Finally, Islamist movement did the expansion in the society who had frustrated and got disappointed because the limited capability in facing the situation of democracy challenges and globalization which became more dynamic.

The expansion of Islamist movement could be actualized because the process of democratic development and globalization which opened the society participation obstacles. Islamist movement was born as a consequence of the transparency from the democratization process; hence they actualized themselves by some ways and equipment which were appropriated with democracy nuances, such as social movement as civil freedom actualization, built mass media, actively involved on taking a choice, until critic toward institution as check and balances process. In this context, Islamist movement presented to snatch the public space away by using the political chances which changed constantly. However, on some things, groups as like Islamist movement also positioned threatening which betrays the democracy principle such as human right, pluralism, and multiculturalism which grow as the democracy development process. According to Barber, that sometimes a forward step is shocked by sudden backup step. In the history of identity confirmation against globalization in the democracy era, holy-war was not the only revolt against democracy and globalization (McWorld) but also plot with it. While, democracy and globalization not only positioning holy-war in danger; but also actively forming, 
activating and promoting it. Holy-war and McWorld not only against each other but also need each other (Barber 2010, 4).

The new formation of Islamic political parties in the postNew Order is not a repetition of the Islamic parties in an authoritarian regime, but a new form that that constructed from a special socio-political circumstance between Islam and the politic-governmental system (Salim 1999, 42). This condition has a similar experience to the proliferation of Islamist movements in the reformasi era which has different meanings to the previous Islamist movement. Islamist actors in the reformation era are now really aware of the democratic condition. Hence, the current proliferation of Islamist movements is not merely read through monolithic analysis; that Islam always ultimately brings resistance. The proliferation of Islamist movement signifies many things related to the adaptation of Islamic values, human rights, freedom and civil society in the democratic country. Thus, the emergence of some Islamist movements today need to be discussed by interdisciplinary studies (Ahyar 2015a).

However, the actions of Islamists should not always be condemned. Several actions of Islamist political activism today is a dialectic process between democratization and Islamization. The latest phenomenon is an activism series of "aksi bela Islam" (defending Islam action). This activism action makes the Islamists show his intimacy with democratic values. The mass rally which attended by hundreds of thousands of people was almost trough ended without conflict. Thus, the pattern of Islamist movements today turned to be more inclusive and democratic. Some intellectuals do not categorize this action into Islamist activism. This argument because the followers of this action are not Islamist movement politically wants to fight Ahok become non-Islamist movement governor in Jakarta. Some followers reasoned that that are merely defending the Quran, not about 
the local elections. Greg Fealy calls this phenomenon as "turning out for Islam, not Islamism” (Fealy 2016). But, i argue that Islamist must take advantage of this incident. So the aksi bela Islam can prove a little bit their propaganda regarding the prohibition of non-Islamist movement leader. Thus, this phenomenon can be seen also as the successful of Islamist movement to influence non-Islamist people.

Nevertheless, On the other hand, the marching cops brigade catchy wear the Islamic identities like surban, cap, and sajadah (prayer mats) while overseeing the process of aksi bela Islam. The unarmed police cordons signify the proximity to the Islamic symbols and readiness for escorting the action peacefully. I argue that this phenomenon is part of the democratization efforts of the state for discovering the new formula of state-religion identities relation. Aksi bela Islam is one movement may describe the Islamist turn to control the public sphere; including the governmental orders. Frequently in some Muslim countries, Islamist groups function as surrogate political arenas where various social tendencies compete for control of institutional position and resources. After the decline of the communism leftist ideologies, especially post-cold war, Islamic movements have successfully gained control over several associations and utilize them to promote a religious notion to entire society (Wiktorowicz 2004).

Finally, the trajectories of Islamism movements in Indonesia make some pattern. When the authoritarian regime holds the power of the country, the Islamist groups arouse with serious contentious politic and brought the number of social-political conflicts. After the wind of democracy blow to the political circumstance, some Islamist groups turn to the protest movement that sounds the common interest of Indonesia like justice, law enforcement and demand free public sphere to express the ideology. The questions whether Islam is compatible with democracy 
or not become irrelevant to discuss in the middle of democracy development in Indonesia. Either Muslims who believes that Islam compatible with democracy or who believe that it is incompatible, both of these current make its own experiences how to merge Islamic norms and democratic values.

\section{Conclusion}

Along the path of democratization, Indonesia cannot escape dealing with Islamist movement which rejects the concept of democracy. As other Islamist movement democratic countries, the trajectory of democratization in Indonesia intertwined with the proliferation of Islamism movement. Indonesia experience indicates that the maturing democracy will transform the pattern of Islamist activism into an adaptive movement with democratic values. Instead, the authoritarian rule (even a country emphasize the procedural democracy) will emerge the radical Islamist activism.

The number of mainstream Islamic organizations which pro-democratic political system in Indonesia cannot be used as legitimacy that Islam is compatible with democracy. Divertingly, the proliferation of Islamist movements which condemn the democratic system does not mean that Islam incompatible with democracy. The hard discussion between compatibility and incompatibility of Islam and democracy only brings subjective debate and monolithic understanding. In the context of democracy, the unity of understanding is not a significance keyword, compatibility and incompatibility is not a big deal. Democracy is talking about diversity in public sphere with no serious conflict. The rise of Islamist political activism does not necessarily prove the failure of Muslims in Indonesia to merge between Islamic norms and democratic value. The phenomenon of the emergence of Islamist movements nowadays precisely confirms that 
democracy in Indonesia has a good trend for caring diversity of religious interpretation in the context of religion-state relations.

Bibliography

Ahyar, Muzayyin. 2015a. "Membaca Gerakan Islam Radikal Dan Deradikalisasi Gerakan Islam." Walisongo: Jurnal Penelitian Sosial Keagamaan 23 (1): 1-26. doi:10.21580/ WS.23.1.220.

— 2015b. "Ahmadiyah Dalam Labirin Syariah Dan Nasionalisme Ketuhaan Di Indonesia." Mazahib: Jurnal Pemikiran Hukum Islam 14 (2). doi:10.21093/mj.v14i2.340.

Al-Chaidar. 1999. Pemikiran Politik Proklamator Negara Islam Indonesia S.M. Kartosoewirjo: Fakta dan Data Sejarah Darul Islam. Jakarta: Darul Falah.

Alfitri. 2008. "Religious Liberty in Indonesia and the Rights of 'Deviant' Sects." Asian Journal of Comparative Law 3 (1): 1-29. doi:10.1017/S2194607800000144.

An-Na'im, Abdullahi Ahmed. 2009. Islam and the Secular State. Universiteit Voor Humanistiek Utrecht. Harvard: Harvard University Press. doi:Book Review.

Barber, Benjamin. 2010. Jihad vs. McWorld: Terrorism's Challenge to Democracy. New York: Random House Publishing Group.

Barton, Greg. 2005. Jemaah Islamiyah: Radical Islamism in Indonesia. Singapore: NUS Press.

Bayat, Asef. 2007. Making Islam Democratic: Social Movements and the Post-Islamist Turn. California: Stanford University Press. 
Budiardjo, Miriam. 2003. Dasar-Dasar Ilmu Politik. Jakarta: Gramedia Pustaka Utama.

Dahl, Robert A., and Ian Shapiro. 2015. On Democracy. Connecticut: Yale University Press.

Dahl, Robert Alan. 1989. Democracy and Its Critics. Connecticut: Yale University Press.

Esposito, John L, and James Piscatori. 1991. "Democratization and Islam.” The Middle East Jurnal 45 (3): 427-40.

Fealy, Greg.2016. "Bigger than Ahok: Explaining the 2 December Mass Rally." Indonesia at Melbourne. December. http://indonesiaatmelbourne.unimelb.edu.au/bigger-than-ahok-explaining-jakartas-2-december-mass-rally/.

Fuller, Graham E. 1992. The Democracy Trap: The Perils of the Post-Cold War World. New York: Dutton.

Geovanie, Jeffrie. 2013. The Pluralism Project: Potret Pemilu, Demokrasi, dan Islam di Amerika. Jakarta: Expose.

Hasan, Noorhaidi. 2008. "Reformasi, Religious Diversity, and Islamic Radicalism after Suharto.” Journal of Indonesian Social Sciences and Humanities 1 (1): 23-51.

Hilmy, Masdar. 2010. Islamism and Democracy in Indonesia: Piety and Pragmatism. Singapore: Institute of Southeast Asian Studies (ISEAS).

Huntington, Samuel P. 2007. The Clash of Civilizations and the Remaking of World Order. New York: Simon and Schuster.

“Indonesia's Democracy Index Report 2009-2013.”2014. Badan Perencanaan Pembangunan Nasional (BAPPENAS), Badan Pusat Statistik, United Nation Development Programme (UNDP) Indonesia. 
Jones, Sidney. 2004. "Political Update 2003: Terrorism, Nationalism and Disillusionment with Reform." In Business in Indonesia: New Challenges, Old Problems. M. Chatib Basri $\&$ Pierre Van Der Eng (Ed). Singapore: Institute of Southeast Asian Studies.

Juergensmeyer, Mark. 1993. The New Cold War? Religious Nationalism Confronts the Secular State. California: University of California Press.

Kahin, George McTurnan. 1952. Nationalism and Revolution in Indonesia. New York: SEAP Publications.

Kurzman, Charles. 2009. The Unthinkable Revolution in Iran. Harvard: Harvard University Press.

Lewis, Bernard. 2002. What Went Wrong?: Western Impact and Middle Eastern Response. New York: Oxford University Press.

Maarif, Ahmad Syafii. 1996. Islam dan Politik: Teori Belah Bambu, Masa Demokrasi Terpimpin, 1959-1965. Depok: Gema Insani.

Nasihin. 2012. Sarekat Islam Mencari Ideologi, 1924-1945. Yogyakarta: Pustaka Pelajar.

Osman, Fathi. 2001. "Islam and Human Rights: The Challenge to Muslims and The World,." In . Markfield UK: The Islamic Foundation.

Panjaitan, Merphin. 2011. Logika Demokrasi: Rakyat Mengendalikan Negara / Merphin Panjaitan. Jakarta: Permata Aksara.

Ricklefs, Merle Calvin. 2008. Sejarah Indonesia Modern 12002008. Jakarta: Penerbit Serambi. 
Salim, Arskal. 1999. Partai Islam dan Relasi Agama-Negara. Jakarta: Jaringan Pendidikan Pemilih Untuk Rakyat.

Schwarz, Adam. 2008. A Nation in Waiting: Indonesia's Search For Stability. Colorado: Westview Press.

Solahudin. 2011. NII Sampai JI: Salafy Jihadisme di Indonesia. Depok: Komunitas Bambu.

Wiktorowicz, Quintan. 2004. Islamic Activism: A Social Movement Theory Approach. Bloomington, Indiana: Indiana University Press. 
This page intentionally left blank 